\title{
Tumpang Tindih Penegekan Hukum di Laut Indonesia
}

\section{Arif Budi Kusuma}

2110622002

\begin{abstract}
Abstrak
Indonesia sebagai poros maritim dunia memiliki laut sebagai penghubung antar wilayah dan batas dari teritorial negara. Pentingnya fungsi laut menimbulkan perlunya penegakan hukum di laut yang baik untuk mempertahankannya. Namun, penegakan hukum di laut dalam yuridiksi nasional Indonesia belum tertata dengan baik. Hal ini dapat dilihat dari posisi kewenangan dalam pengaturan terkait keamanan kemaritiman nasional yang saling tumpang tindih antar lembaga seperti Tentara Nasional Indonesia Angkatan Laut (TNIAL), Badan Keamanan Laut (Bakamla), dan Kesatuan Penjagaan Laut dan Pantai (KPLP). Tulisan ini akan menganalisis lembaga negara yang menjadi coast guard di Indonesia. Selain itu mengenai permasalahan penegakan hukum di laut tidak dapat dilaksanakan dengan baik yang disebabkan oleh ketidakharmonisan antar peraturan perundang-undangan. Penulisan ini menggunakan metode yuridis normatif yang menggunakan pendekatan undang-undang. Dari penulisan ini akan diperoleh hasil mengenai analisis harmonisasi penegakan hukum dan faktor yang menjadi kendala dalam penegakan hukum keamanan laut di Indonesia.
\end{abstract}

Kata Kunci : TNI-AL, Bakamla, KPLP, Tumpang Tindih, Coast Guard

\begin{abstract}
Indonesia as the world's maritime axis has the sea as a liaison between regions and borders of the country's territory. The importance of the function of the sea raises the need for good maritime law enforcement to maintain it. However, maritime law enforcement in Indonesia's national jurisdiction has not been well organized. This can be seen from the position of authority in regulations related to national maritime security that overlaps between institutions such as the Indonesian Navy (TNI-AL), the Maritime Security Agency (Bakamla), and the Marine and Coast Guard Unit (KPLP). This paper will analyze the state institutions that serve as coast guards in Indonesia. In addition, the issue of maritime law enforcement cannot be implemented properly due to the disharmony of laws and regulations. This writing uses a normative juridical method that uses a law approach. From this paper, the results will be obtained regarding the analysis of harmonization of law enforcement and the factors that become obstacles in the enforcement of maritime security law in Indonesia.
\end{abstract}

Keywords: TNI-AL, Bakamla, KPLP, Overlapping, Coast Guard 